\title{
DEMAM BERDARAH DENGUE (DBD) DI BANJAR TEGAL, TEGALLALANG GIANYAR
}

\author{
Dengue Fever At Banjar Tegal Tegallalang Gianyar
}

\author{
I Wayan Artana \\ Dosen S1 Keperawatan, STIKES Bina Usada Bali \\ Korenpondensi: wayan.artana473@gmail.com
}

\begin{abstract}
ABSTRAK
Penyakit Demam Berdarah Dengue (DBD) merupakan penyakit infeksi yang angka kematiannya masih cukup tinggi di Indonesia. Penyakit musiman ini mempunyai siklus 5 tahunan untuk menimbulkan kejadian luar biasa (KLB). Di Indonesia tahun 2015 terjadi sebanyak 129.179 kasus dengan kematian 1.240 orang. Di Provinsi Bali tahun 2015 terjadi 9.826 kasus dengan jumlah kematian 19 orang. Di Gianyar tahun 2015 kasus DBD sebanyak 2.032 dengan jumlah kematian 6 orang dan tahun 2016 terdapat 1.758 kasus kasus dengan jumlah kematian delapan orang. Di wilayah kerja Puskesmas 1 Tegallalang Banjar Tegal menempati urutan pertama kasus DBD dengan jumlah 48 kasus dengan tidak ada kematian. Metode penelitian ini adalah kualitatif berparadigma interpretative, dengan desain studi kasus. Tidak semua informan mengetahui bahwa penyakit DBD disebabkan oleh virus. Ada beberapa diantaranya mengatakan penyebabnya adalah nyamuk. Kebanyakan informan tahu bahwa penularan DBD melalui nyamuk. Lingkungan Banjar Tegal Tegalalang cukup bersih, dikarenakan masyarakatnya rutin melakukan gotong royong seminggu sekali, membersihkan got, melakukan kegiatan 3M, dan juga melakukan fogging saat ada kasus DBD. Saat observasi, lingkungan sudah terlihat tidak ada air tergenang, sampah tidak berserakan, kaleng bekas tidak ada, tanaman di halaman rumah teratur. Hasil penelitian ini dapat dipakai sebagai bahan dan pegangan bagi masyarakat Banjar Tegal untuk meningkatkan pemahaman masyarakat tentang pencegahan dan penularan DBD dengan cara memelihara kebersihan lingkungan.
\end{abstract}

Kata kunci: DBD, nyamuk, virus

\begin{abstract}
Dengue Fever is a disease infected by mosquito. Indonesia in 2015 about 129,179 with death number about 1.240. In Bali province in 2015 happen 9.826 with death number 19 cases. Gianyar in 2105 dengue fever cases about 2032 with death number six and in 2016 about 1.758 cases. Puskesmas I Tegallalang showed that Banjar Tegal Tegallalang ranked first position than other banjar. The study method was qualitative paradigm interpretative with case study design. The informant not all knew that fever dengue caused by virus, others said that caused by mosquito. Mostly infected through mosquito vector. The environment was pretty clean, community took mutual cooperation once a week. Clean the drain containing puddle, did $3 M$ and fogging when the fever dengue case happen. When observation, the environment had seen no water flooded, garbage littered, canned former, plant in house well-organized. This study result can be used as example to improve the public understanding about prevention and infection of dengue fever has good impact to clean environment.
\end{abstract}

Keywords: Dengue fever, mosquito, virus 


\section{Pendahuluan}

Kasus Demam Berdarah Dengue (DBD) di Amerika, Asia Tenggara, dan pasifik Barat melebihi 1,2 juta pada tahun 2008, dan lebih dari 3 juta pada tahun 2013. Pada tahun 2013 terdapat 2,35 juta kasus demam berdarah dilaporkan di Amerika saja, yang 37.687 kasus demam berdarah lanjut. Terhitung sejak tahun 1968 hingga tahun 2009, World Health Organization (WHO) mencatat Negara Indonesia sebagai negara dengan kasus DBD tertinggi di Asia Tenggara.

Di Indonesia, pada tahun 2015, jumlah penderita DBD yang di laporkan sebanyak 129.179 kasus dengan jumlah kematian 1.240 orang. Terjadi kenaikan jumlah kasus dibandingkan dengan tahun 2014 yang sebesar 90.245. Kasus DBD di Provinsi Bali tahun 2015 menurut kepala Pengendalian Penyakit dan Penyehatan Lingkungan (P2PL) Dinas Kesehatan Provinsi Bali terjadi 9.826 kasus DBD, sedangkan Kabupaten Gianyar menjadi daerah yang memiliki banyak kasus DBD yakni sebanyak 2.032 kasus. Kecamatan Tegallalang memiliki kasus DBD terbanyak (Dinkes Gianyar, 2016). Kepala Puskesmas 1 Tegallalang menyatakan terdapat 54 kasus DBD dengan Banjar Tegal menempati urutan pertama, yaitu 48 orang. DBD merupakan salah satu masalah umum kesehatan masyarakat di Indonesia. Jumlah kasusnya cenderung meningkat dan penyebarannya bertambah luas. Keadaan ini erat kaitannya dengan peningkatan mobilitas penduduk sejalan dengan lancarnya transportasi, kebersihan lingkungan kurang yang memungkinkan nyamuk aedes aegypti cepat berkembangbiak (Depkes RI, 2015).

Masa inkubasi virus dengue berkisar selama 4-10 hari (biasanya 4-7 hari), nyamuk yang terinfeksi mampu menularkan virus selama sisa hidupnya. Pasien yang sudah terinfeksi dengan virus dengue dapat menularkan infeksi (selama 4-5 hari, maksimum 12 hari) melalui nyamuk aedes aegypti setelah gejala pertama muncul. Faktor curah hujan yang tinggi sepanjang tahun, genangan air pada barang-barang bekas seperti kaleng, ban bekas, tanaman hias, dan perilaku masyarakat yang kurang memperhatikan kebersihan lingkungan menjadi faktor pendukung menyebarnya DBD (Najmah, 2015). Selain itu, adanya kebiasaan masyarakat menampung air untuk keperluan sehari-hari seperti menampung air hujan, menampung air sumur pada bak mandi atau drum/tempayan, apalagi jarang dikuras berpotensi sebagai tempat perkembangbiakan nyamuk. Ada pula kebiasaan masyarakat menyimpan barangbarang bekas yang dapat menampung air hujan sehingga menjadi tempat berkembangbiaknya nyamuk. Begitu pula kurang melaksanakan kebersihan lingkungan, tidak melaksanakan 3M Plus (menguras, menutup, dan mengubur plus menaburkan larvasida, memelihara ikan pemakan jentik, serta pemakaian insektisida rumah tangga) untuk mencegah DBD belum terlaksana secara efektif (Pratamawati, 2012).

Kesehatan lingkungan pada hakikatnya adalah suatu kondisi atau keadaan lingkungan yang optimum sehingga berpengaruh terhadap terwujudnya status kesehatan. Usaha kesehatan lingkungan adalah suatu usaha untuk memperbaiki atau mengoptimumkan lingkungan hidup manusia agar merupakan media yang baik untuk terwujudnya kesehatan yang optimum bagi manusia yang hidup di dalamnya (Notoatmojo, 2011).

\section{Demam Berdarah Dengue (DBD)}

Penyakit DBD disebabkan oleh virus Dengue dengan tipe DEN 1, DEN 2, DEN 3, dan DEN 4. Virus tersebut termasuk dalam group $B$ Arthropod borne viruses (arboviruses). Virus Dengue merupakan virus RNA rantai tunggal, genus flavivirus, terdiri dari 4 serotipe yaitu DEN-1, DEN-2, DEN-3, dan DEN-4. Struktur antigen ke-4 serotipe ini sangat mirip satu dengan yang lain, namun antibodi terhadap masingmasing serotipe tidak dapat saling memberikan perlindungan silang (Zulkoni, 2010).

DBD ditemukan di daerah tropis dengan penyebaran geografis yang mirip dengan malaria. Penularannya melalui gigitan nyamuk aedes aegypti yang hidup di dalam dan di sekitar rumah (Kementerian Kesehatan RI, 2012). 
Penyakit ini ditandai dengan panas (demam) dan disertai kadang dengan perdarahan dibawah kulit, bahkan perdarahan yang berat.

\section{Metode}

Penelitian ini menggunakan metode kualitatif berparadigma interpretative dengan desain studi kasus. Penelitian studi kasus adalah studi yang mengeksplorasikan suatu masalah dengan batasan terperinci, memiliki pengambilan data masalah yang mendalam (Saryono \& Anggreni, 2013). Penelitian ini akan mengetahui persepsi masyarakat tentang penyakit demam berdarah dengue (DBD) dari perspektif penyebab dan penularan serta dampaknya terhadap kebersihan lingkungan.

\section{Hasil}

Tidak seluruh responden mengetahui bahwa penyebab DBD adalah virus. Beberapa informan mengetahui penyebab DBD itu adalah nyamuk. Seperti yang disampaikan oleh beberapa informan, yaitu:

Informan 1: "Menurut saya DBD adalah penyakit yang disebabkan oleh nyamuk aedes aegypti karena lingkungan yang kurang bersih tapi kebanyakan virus saat ini yang menyebabkan demam berdarah"

Informan 2: "Menurut saya DBD secara umum adalah kebetulan berbicara masalah $D B D$ sebenarnya banyak sekali yang terlibat karena masalah $D B$ bukan hanya disebabkan satu dua orang bagaimana masyarakat bisa melindungi dirinya sendri dengan cara paling tidak lingkungannya bersih sesuai anjuran dari pemerintah melakukan kita wajib secara rutin melakukan $3 M$ biar tidak terkena bisanya penyebabnya adalah virus yang dibawa oleh nyamuk demam berdarah kemudian dia menggigit orang yang kena demam berdarah nika intinya seperti itu. "

Informan 5: "Menurut saya DBD adalah penyakit yang berbahaya yang mematikan penyakit yang disebabkan oleh virus-virus itu dibawa oleh nyamuk menggigit orang di sekitar sini.

Ada juga yang mengatakan penyebab DBD tersebut adalah nyamuk, seperti yang dikatakan oleh:
Informan 3: "Menurut saya DBD kalau penyakit demam berdarah yang tiyang dengar dengar kan penyebabnya dari nyamuk yang awalnya adanya istilah genangan-genangan air mungkin di dalam di WC istilahnya di belakang mungkin tabung-tabung yang berisi air nanti nyamuknya berkembang di sisa nyamuknya bertelur jadi jentik nyamuk aedes nanti sempat mungkin warga tiyang sendiri digigit nyamuk itu pengetahuan yang saya tau selama ini tapi perkembangan jaman ada katanya virus beda penyebaran virus gitu itu yang saya ketahui selama ini dari masyarakat kalau dari ilmu kedokteran saya belum tau pasti"

Informan 4: "Menurut saya DBD penyakit demam berdarah nika kan katanya disebabkan oleh jentik nyamuk tapi saat itu kira-kira gak nyamuk saat saya sakit menderita penyakit itu ketularan virus lah saat itu setelah nganter-nganter yang lain akhirnya saya kena demam berdarah itu." Lebih banyak mengetahui bahwa lingkungan berperanan untuk timbulnya DBD. Seperti penuturan dari:

Informan 1: "Menurut pandangan saya kalau misalnya lingkungannya bersih masyarakat peduli $3 M$ itu yang berperan banget dengan angka kejadian DBD disini" Informan 2: "Menurut pandangan saya ini sangat berkaitan kalau lingkungan sudah bersih nika pasti terputus nika siklus nyamuknya seperti yang saya bilang tadi lingkungan nika memang harus bersih guna mengurangi kejadian DBD niki. Fogging disini juga biasa nika dilakukan semenjak kejadin yang banyak nika mulai ditekankan membangun lingkungan bersih."

Informan 3: "Menurut pandangan saya kalau masyarakat disini kalau bilang tuna rungu ya kalau udah dibilang nika ada wabah nika otomatis antusias nika warga disini antisipasi dengan kebersihan lingkungan disini yang jelas dampak nika tinggi sekali kalau kita nika gak peduli dengan lingkungan nika secara otomatis nika tular menular nika cepet terhadap penyakit seharusnya masyarakat yang harus ada partisipasi dan kegiatannya disini"

Informan 4: "Menurut pandangan saya kalau disini mungkin karena manusianya keluar sana sini bergaul sana sini mungkin 
itu yang sangat berpengaruh kalau lingkungan sini sekarang tidak terlalu kotor karena sering nika dikontrol petugas disini. Di sini juga nika sudah dari dulu di sini melalukan 3M itu"

Informan 5: "Menurut pandangan saya belum maksimal belum ada tidak lanjut masih tetap seperti dulu walaupun sudah ada kejadian DBD yang banyak masyarakat disini belum sadar akan kebersihan masih jorok seperti dulu got- got itu masih ada genangan air pas hujan juga genangan air itu tetap ada."

\section{Pembahasan}

Penyakit DBD yang merupakan penyakit menular, mencegah dan mengobati penyakit menular apalagi ada hubungannya dengan lingkungan sekitar tidak menutup kemungkinan masyarakat ikut berperan serta untuk membangkitkan masyarakat sangat tergantung persepsi masyarakatnya. Masyarakat mempunyai persepsi yang berbeda-beda. Informan 1 dan 3 mempunyai persepsi DBD adalah penyakit yang disebabkan oleh nyamuk. Menurutnya DBD adalah penyakit yang disebabkan oleh nyamuk aedes aegypti karena lingkungan yang kurang bersih. Penyebabnya dari nyamuk yang berawal dari adanya genangan-genangan air mungkin di dalam WC, istilahnya di belakang, mungkin juga pada tabung-tabung yang berisi air, sebagai tempat nanti nyamuknya berkembang.

Penyakit DBD merupakan penyakit yang disebabkan oleh virus. Beberapa informan mengatakan demikian. Menurut informan, DBD penyakit demam penyebabnya adalah virus yang dibawa oleh nyamuk demam berdarah kemudian dia menggigit orang yang kena demam berdarah itu sehingga terjadi penyebaran. Virus dibawa oleh nyamuk, lalu nyamuklah yang menggigit manusia.

Faktor lingkungan sangat berperan untuk terjadinya serangan DBD, saluran air yang kurang bersih, faktor imigrasi, PHBS yang kurang maksimal, kaleng bekas berisi genangan air, dan kebersihan lingkungan. Dilihat dari informan 1, 3, 4, dan 5 penyebab DBD adalah keadaan got-gotnya kurang diperhatikan lingkungan yang kurang bersih. Adanya kaleng-kaleng bekas berisi genangan air. Got di jalan seharusnya bersih tidak ada lagi limbah dari industri rumah tangga, ada kaleng bekas isi genangan air. Kemudian yang kedua faktor imigrasi perpindahan warga, ada yang kerja di luar desa atau ada yang kuliah di luar. Mereka yang terkena dan pulang, merekalah yang mungkin membawa penyakitnya. Apalagi seperti yang diungkapkan warga bahwa PHBS yang belum bagus dapat juga menyebabkan DBD. Persepsi sebagian besar informan tentang pandangan mengenai hubungan kebersihan lingkungan terhadap kejadian DBD memiliki perbedaan, informan ada yang beranggapan kebersihan lingkungan sangat berpengaruh terhadap kejadian DBD, masyarakat peduli dengan $3 \mathrm{M}$, masyarakat belum sadar akan kebersihan lingkungan, adanya interaksi masyarakat di sini dengan masyarakat di luar desa. Pandangan informan 3, 4, dan 5 jika misal lingkungannya bersih serta masyarakat peduli $3 \mathrm{M}$, itu yang berperan dengan angka kejadian DBD di sini. Lingkungan sudah bersih pasti cepat siklus nyamuknya berhenti. Kegiatan fogging biasa dilakukan semenjak tingginya kejadian DBD di sini. Kebersihan lingkungan di sini yang jelas dampaknya tinggi sekali, jika tidak peduli dengan lingkungan otomatis tular menular penyakit akan terjadi. Seharusnya masyarakat ada partisipasi dan kegiatanya di sini. Informan 4, berpandangan adanya DBD di banjarnya karena DBD dibawa dari luar, jika di sini mungkin karena manusianya keluar sana sini, bergaul sana sini, hal tersebut yang sangat berpengaruh. Kalau lingkungan sini sekarang tidak terlalu kotor karena sering dikontrol petugas di sini. Sudah dari dulu di sini melakukan $3 \mathrm{M}$ itu. Pandangan informan 5, sepertinya sedikit tidak sejalan dengan informan lainnya mereka berpandangan masalah lingkungan belum maksimal belum ada tidak lanjut, masih tetap seperti dulu walaupun sudah ada kejadian DBD yang banyak. Masyarakat di sini belum sadar akan kebersihan masih jorok seperti dulu, got-got masih ada genangan air ketika hujan.

\section{Kesimpulan}

Hasil penelitian yang dilakukan di Banjar Tegal, Tegallalang Gianyar mengenai 
persepsi masyarakat tentang penyakit Demam Berdarah Dengue (DBD) dari perspektif penyebab dan penularan serta dampaknya terhadap kebersihan lingkungan di Banjar Tegal, Tegallalang Gianyar dapat ditarik kesimpulan sebagai berikut:

Demam berdarah dengue merupakan penyakit yang disebabkan oleh nyamuk aedes aegypti, virus dengue dan ditularkan oleh nyamuk Aedes aegypti.

Penyakit demam berdarah dengue disebabkan oleh karena lingkungan yang kurang bersih, got-got yang masih berisi genangan air, kaleng-kaleng bekas yang masih berisi genangan air, migrasi penduduk, dan PHBS masyarakat yang belum maksimal.

Kebersihan lingkungan memiliki dampak yang tinggi terhadap kejadian DBD, perlunya melakukan $3 \mathrm{M}$ secara rutin dan keaktifan masyarakat bersama-sama membangun lingkungan yang bersih dan sehat guna mengurangi angka kejadian DBD di lingkungan masyarakat di Banjar Tegal, Tegallalang Gianyar.

\section{Daftar Pustaka}

Anggraeni. (2010). Kesehatan Lingkungan. Jakarta: Rineka Cipta.

BPS. (2015). Bali Dalam Angka 2015. Denpasar: BPS Provinsi Bali

Depkes RI. (2015). Pencegahan dan Pemberantasan Demam Berdarah Dengue di Indonesia. Jakarta: Direktorat Jenderal pp \&PL.

Depkes RI. (2011). Tatalaksana demam berdarah dengue (DBD). Jakarta: Ditjen PP \& PL.

Haryanto. (2008). Persepsi dan Perilaku Manusia. Tersedia di. http://haryantoruz.Wordpress.Com/200

8. Diakses pada tanggal 25 September 2016

Hidayat. (2007). Metode Penelitian Kesehatan Paradigma Kualitatif. Jakarta: Health Books.

IDAI. (2012). Penatalaksanaan Demam Berdarah Dengue (DBD). Jakarta: EGC.

Kementrian Kesehatan RI. (2010). Demam Berdarah Dengue. Jakarta: Kementrian Kesehatan RI.
Kementrian Kesehatan RI. (2012). Profil Data Kesehatan. Jakarta: Kementrian Kesehatan RI.

Mardiana. (2010). Demam Berdarah Dengue. Jakarta: Rineka Cipta.

Miller, K. (2005). Communication theories: perspectives, processes, and contexts. Jakarta: 2nd Ed.

Najmah. (2015). Kejadian Demam Berdarah Dengue (DBD). Jakarta: Rineka Cipta.

Soekidjo Notoatmojo. (2011). Kesehatan Masyarakat Ilmu dan Seni / Ed.2.Jakarta: Rineka Cipta.

Pieter \& Lubis. (2010). Perumahan Sehat Jakarta: Depkes RI.

Sunaryati. (2011). Penyakit Paling Sering Menyerang Dan Sangat Mematikan. Jogjakarta: Alfa Beta.

Saryono \& Anggreni. (2013). Metodologi Penelitian Kualitatif dan Kuantitatif dalam Bidang Kesehatan. Yogyakarta: Nuha Medika.

Suryana (2007). Tahap-tahapan penelitian kualitatif. Bandung: Alfa Beta.

Silalahi, U. (2009). Metode Penelitian Bandung: Unpar Press.

World Health Organization (WHO). (2005). Pencegahan Dan Pengendalian Dengue Dan Pedoman Demam Berdarah Dengue. Jakarta: WHO Press.

World Health Organization (WHO).2012. Global Strategi For Dengue Prevention And Control 2012- 2020. WHO Library Catalonguing In Publication Data: WHO Press.

World Health Organization (WHO). (2015). Fack Sheet Dengue And Severe Dengue. Tersedia di Http ://Www.Who.Int/Mediacentre/Factshee $\mathrm{t} / \mathrm{Fs} 117 / \mathrm{En} /$. Diakses pada tanggal 30 September 2016

Zulkoni, A. (2010). Parasitologi. Yogyakarta: Nuha Medika. 